the project a number of valuable facilities, including marine biology laboratories, oceanographic vessels and some specialized fishing equipment. Certain other facilities, including the 360-ton oceanographic ship Calypso, may also be available through the Institute. The Monaco Government will contribute 200,000 French new francs for each year of the research project. The Agency will appoint a chief scientist to be in charge of the research and provide other personnel as well as specialized equipment and technical supplies. Agency fellowships will be awarded for training in connexion with the research project.

\section{Co-operative Nuclear Research}

IN a written answer to a question in the House of Commons on March 7 as to the projects in which the United Kingdom is participating under the auspices of the European Nuclear Energy Agency, Mr. D. Freeth, the Parliamentary Secretary for Science, named the Dragon project at Winfrith Heath for the development of the high-temperature gas-cooled reactor and the Halden project in Norway for the development of a boiling-water reactor. The United Kingdom is also co-operating fully in the general work of the Agency through membership of specialist panels, committees and symposia. The Dragon project is managed by an international board, the United Kingdom representatives on which are appointed by the Atomic Energy Authority. According to the report for the year ended March 31, 1960, a start has been made on the construction of the experimental reactor, and Mr. Freeth understood that satisfactory progress is continuing. In reply to other questions, Mr. Freeth said that between 35 and 40 graduate physicists, drawn from physics departments in four universities, are making regular use of the facilities at the Rutherford Laboratory at the National Institute for Research in Nuclear Science, Harwell, and teams from two more physics departments would shortly be doing so. Present estimates indicate that the annual output of qualified scientists and technologists in Britain should reach 20,000 by about 1964, or after only eight years, instead of the 10-15 years recommended by the Scientific Man-power Committee of the Advisory Council on Scientific Policy.

\section{Toxic Chemicals and Wild Life}

IN reply to a question in the House of Lords on March 9, the Joint Parliamentary Secretary to the Ministry of Agriculture, Fisheries and Food, Earl Waldegrave, said the attention of the Government had been directed to the report issued on February 22 by the joint committee of the British Trust for Ornithology and the Royal Society for the Protection of Birds on the effect upon birds and mammals of toxic chemicals used in agriculture. Comprehensive measures for dealing with this problem were agreed at a meeting last December convened by the Department, at which representatives of these two bodies were present, as well as delegates from the Council of Nature, the National Farmers' Union and the Association of British Manufacturers of Agricultural Chemicals. The measures agreed included a survey by the Ministry's pests officers of reported cases of unusual deaths among birds, foxes and badgers, and the results of the survey are to be reviewed with the interested organizations after this spring. The need for further research into the effects of the use of toxic chemicals in agriculture is being examined by a research study group appointed last year. While the Minister thought that these new arrangements would provide valuable evidence on which to base any further action which may seem necessary, he wished it to be widely known that the Government would welcome full information from naturalists or other interested persons about suspected poisoning of birds or mammals by toxic chemicals.

This reply did not entirely satisfy Viscount Elibank, Lord Hurcomb, Lord Shackleton and others, and points were pressed about the omission of any reference to possible dangers to wild life from the Ministry's 1961 list of approved chemicals, the desirability of independent inquiry and the effectiveness of co-ordination between the Ministry, the Agricultural Research Council and the Nature Conservancy. Lord Waldegrave said that he understood that an appendix to the notification scheme dealing with wild life is under discussion with the Nature Conservancy and other bodies, and he undertook to consider embodying a statement in the list itself in due course. Some concern was expressed as to whether sufficient research is proceeding, and Lord Hailsham, Minister for Science, agreed that co-operation could be improved and promised to consider issuing a statement as to the extent of research in progress. He did not, however, enter on the question of relations or co-ordination between the Agricultural Research Council and the Nature Conservancy, on which he was challenged by Lord Shackleton.

\section{National Research Development Corporation of India}

The sixth annual report and statement of accounts of the National Research Development Corporation of India covers the year ended March 31, 1960, in which fifty inventions were reported for development by eleven research institutions and individuals, bringing the total to 553 , of which 397 are effectively in hand (Pp. 25. New Delhi : National Research Development Corporation of India, 1960). Thirty licences were negotiated and five processes went into production, making the total licensed and in production 37, with 51 licensed, but not yet in production. A new project on lightning arrestors has been sanctioned at the Indian Institute of Science, Bangalore, at an estimated cost of Rs. 1.60 lakhs. Installation of the pilot plant for phthalic anhydride at the Central Fuel Research Institute, Jealgora, is in hand and that for the de-ionization of cane juice at the National Sugar Institute, Kampur, has been installed. Pilot plant for white cement from felspar and $a$ semi-commercial fluidized bed unit for textiles processing are being created.

\section{New West Durham Borehole}

Aт a recent meeting of the Geological Society at Burlington House, Piccadilly, Prof. K. C. Dunham, of the University of Durham, announced the results of a borehole that is being made at Rookhope in West Durham, and financed by the Department of Scientific and Industrial Research. Prof. Dunham, who has carried out extensive work on the metalliferous deposits of the Pennines, has for many years held the view that these continue to greater depths than have so far been exploited, and that they are related to an underlying granite mass. Support for the latter view has come from measurements of the 